\title{
Bauhiniastatin-1 alleviates diet induced obesity and lipid accumulation through modulating PPAR- Y/AMPK expressions: In-vitro, in-vivo and in-silico studies.
}

Karunakaran Reddy Sankaran

Sri Venkateswara University

Lokanatha Oruganti

Sri Venkateswara University

Muni Swamy Ganjayi

Sri Venkateswara University

Venkataramaiah Chintha

Sri Venkateswara University

Muni Kesavulu Muppuru

Sree Vidyanikethan Engineering College

Appa Rao Chippada

Sri Venkateswara University

Kameswara Rao Badri

Morehouse School of Medicine

Balaji Meriga ( $\sim$ balaji.meriga@gmail.com )

Sri Venkateswara University https://orcid.org/0000-0001-9238-5523

\section{Research}

Keywords: Adipogenesis, AMPK, Bauhiniastatin-1, Diet-induced obesity, PPAR-y, In-silico docking, Lipid accumulation.

Posted Date: March 17th, 2021

DOl: https://doi.org/10.21203/rs.3.rs-302339/v1

License: (c) (i) This work is licensed under a Creative Commons Attribution 4.0 International License.

Read Full License 


\section{Abstract}

Background: Consumption of energy dense foods and sedentary lifestyles have led to high prevalence of obesity and associated disorders. Intensive research efforts have focussed to develop effective alternative therapeutics from plant sources. Bauhiniastatins have been reported to possess antineoplastic activity. In the present study, Bauhiniastatin-1 (BSTN1) was isolated and purified from Bauhinia purpurea and evaluated for its therapeutic efficacy against adipogenesis and obesity using high fat diet (HFD)-induced obese rodent model and 3T3-L1 cells.

Methods: We performed in-vitro experiments like MTT assay, Oil Red O (ORO) stain, cellular lipid content, glycerol release and RT-PCR analysis in 3T3-L1 cells. In-vivo parameters like body weight gain, body composition, plasma adipokines, serum \& liver lipid profiles, liver marker enzymes, western blot analysis and histopathological examination were conducted in rat model. In addition, molecular docking studies were also performed to understand interaction of BSTN1 with peroxisome proliferator-activated gamma receptor (PPAR- $\gamma$ ) and AMP-activated protein kinase (AMPK) which supported our experimental results.

Results: BSTN1 at $20 \mu \mathrm{M}$ significantly $(p<0.001)$ inhibited cell differentiation and lipid accumulation of 3T3-L1 adipocytes. Mechanistic studies showed that mRNA expression of key adipogenic markers, PPAR$\gamma$, fatty acid synthase (FAS) and sterol-regulatory element-binding protein-1 (SREBP1) were downregulated while AMPK was up-regulated by BSTN1. Oral administration of BSTN1 ( $5 \mathrm{mg} / \mathrm{kg}$. b.wt.) to HFD-induced obese rats substantially decreased body weight gain, fat mass, serum and liver lipid levels and promoted integrity of hepatic and adipose tissue architecture compared to HFD-control rats. In BSTN1 administered groups, decreased serum aspartate transaminase (AST) and alanine aminotransferase (ALT) levels, decreased plasma leptin but increased adiponectin levels were noted. Western blot analysis of adipose and hepatic tissues collected from BSTN1 treated rats showed decreased expression level of PPAR-y but increase in AMPK expression relative to the untreated group. Insilico studies showed strong binding interactions of BSTN1 against PPAR- $\gamma$ and AMPK, the key molecules of adipogenesis and obesity.

Conclusions: Taken together, the results suggest that BSTN1 could be promising molecule for the treatment of diet-induced obesity and non-alcoholic fatty liver disease (NAFLD).

\section{Background}

Bauhinia purpurea Linn. is a fast-growing medium sized flowering plant belonging to Fabaceae family, commonly called with different names like purpure bauhinia, butterfly tree, orchid tree, camel's foot tree, and native species of south-east Asian countries including China and India. It is an invasive species as well grown in Africa, North America, South America and Oceania. This plant species is rich in phytochemicals like bauhiniastatins, isoquercitin, lutein, $\beta$-sitosterol, pacharin, astragalin, stigmasterol, kaempferol and lupeol etc., [1, 2]. Its leaves, flowers and seeds are eaten along with rice in parts of some south east Asian countries. This plant is reported to possess anti-diabetic, anti-inflammatory, 
antimicrobial, analgesic and anti-cancerous activities and hence used in traditional and folk medicine to treat various diseases [3].

Obesity, once considered as a cosmetic issue, has drawn tremendous attention in recent times because of its critical role in metabolic syndrome disorders. The excess calories consumed than expended are stored in adipose tissue (AT), liver and muscle, and if it continues for longer periods leads to obesity, NAFLD and associated disorders [4]. Non-alcoholic fatty liver disease (NAFLD) impacts almost $25 \%$ of adults in the general population and includes a spectrum of diseases ranging from steatosis to non-alcoholic steatohepatitis. This condition is an independent risk factor for cardiovascular diseases, diabetes mellitus and all-cause mortality $[5,6,7]$. Moreover, recent reports have linked obesity to high severity in COVID-19 infected patients [8]. As there are very limited non-surgical therapeutic options and in view of the immense demand for drugs to treat obesity and NAFLD and considering the adverse effects associated with existing drugs, research efforts to develop natural product-based therapeutics have drawn much attention $[9,10,11]$. In our previous study, we reported the anti-hyperlipidemic activity of bark extract of Bauhinia purpurea Linn. [12]. In the present study, we have made an attempt to isolate and purify the active principle, Bauhiniastatin-1, evaluated its anti-NAFLD and anti-obesity activity and underlying molecular mechanisms using diet induced obese rat model. Adipogenic, lipogenic and lipolytic studies are complemented using the most widely used white adipogenesis cell culture model of 3T3-L1 preadipocytes. In addition, in silico molecular docking studies were carried out to understand the mechanisms of action of BSTN1.

\section{Methods}

\section{Chemicals}

Dulbecco's Modified Eagle's Medium (DMEM), fetal bovine serum (FBS), 3isobutyl1 methylxanthine (IBMX), penicillin and streptomycin, isopropanol, insulin, dexamethasone (DEXA) were procured from Thermo Scientifics, USA. MTT (3-(4, 5-dimethylthiazol-2-yl)-2, 5-diphenyltetrazolium bromide) and Oil-RedO (ORO) stain were procured from Sigma Aldrich, USA. Analytical Grades' of other solvents, chemicals and reagents were to be utilized for the experiments.

\section{Isolation and purification of Bauhiniastatin-1 (BSTN1)}

The bark of B. purpurea was collected from the Seshachalam forests, Tirupati, Andhra Pradesh, India. It is authenticated by taxonomist in the department of Botany, Sri Venkateswara University, Tirupati, voucher number is 136 and specimen was preserved in departmental herbarium. The bark of $B$. purpurea was powdered, extracted with ethanol and further fractionated by column chromatography using different solvents [12]. The collected fractions were subjected to LC-MS analysis on 6520 Accurate Q-TOF (Agilent Santa Clara, CA) mass spectrometer to identify the major compounds. Bauhiniastatin-1 was purified using an HPLC system equipped with a binary gradient system, a variable UV-VIS-detector and a Rheodyne Model 7725 injector with a loop size of $20 \mu \mathrm{L}$, and an integrator. Reverse phase chromatographic analysis was carried out in isocratic conditions using a C-18 reverse phase column (250 
$x 4.6 \mathrm{~mm}$ id., $5 \mu \mathrm{L} \mathrm{C}-18)$ at $40^{\circ} \mathrm{C}$. Mobile phase consisted of methanol:water (20:80 v/v) with a flow rate of $1 \mathrm{~mL} / \mathrm{min}$. The detection of compounds was performed at $220 \mathrm{~nm}$. A single sharp peak at $5.942 \mathrm{~min}$ of retention time was identified as BSTN1 [13].

\section{Cell culture and differentiation of adipocytes}

The 3T3L1 pre-adipocytes of American Type Culture Collection (ATCC) cells were maintained and cultured in DMEM supplemented with $10 \% \mathrm{FBS}$ at $37^{\circ} \mathrm{C}$ in a humidified atmosphere with $5 \% \mathrm{CO}_{2}$. For adipogenesis studies, 3T3-L1 were grown to confluence, cells were stimulated with adipogenesis differentiation medium of induction (DMI) consisting of DMEM, 5\% FBS, $0.5 \mathrm{mM} \mathrm{IBMX}, 1 \mu \mathrm{M}$ DEXA and $10 \mu \mathrm{g} / \mathrm{mL}$ insulin for 2 days followed by treating cells with differentiation medium (DMEM with $5 \%$ FBS and $10 \mu \mathrm{g} / \mathrm{mL}$ insulin) for additional 8-10 days [14]. All the media that we used contained $100 \mathrm{IU} / \mathrm{mL}$ penicillin and $100 \mathrm{mg} / \mathrm{mL}$ streptomycin. A volume of $0.01 \%$ DMSO was used as vehicle control for invitro experiments. For evaluating anti-adipogenic effects of BSTN1, 3T3-L1 cells cultured and adipogenesis was induced in 12 well plates with different concentrations of BSTN1 $(5,10$ and $20 \mu \mathrm{M})$ in differentiation medium. The adipocytes were stained for neutral lipids (lipid droplets) and observed under a bright field microscope or used for other studies.

\section{Cytotoxicity studies / Cell viability assay (MTT assay)}

The 3T3L1 preadipocytes were cultured in DMEM and cell viability assays were conducted as previously described $[15,16]$.

\section{Determination of adipocyte lipid content using quantitative Oil Red 0 staining}

Lipid contents in adipocytes were visualized as well as measured using Oil Red $\mathrm{O}(\mathrm{ORO})$ staining $[17,18]$.

\section{Lipolysis studies}

The lipolysis studies were conducted by measuring glycerol levels released into the cell culture medium, using commercial kit (Lipolysis assay kit, ab185433, Abcam, Shangai) following manufacturer's instructions [19]. The glycerol content was expressed as nmol/well.

\section{RT-PCR studies}

Total RNA was isolated from 3T3-L1 cells by using tri-reagent (Sigma Aldrich, USA) according to manufacturer's protocol and reverse transcribed to obtain CDNA using CDNA synthesis kit (Applied Bio Systems, Foster City, USA) [20]. Two nano grams of cDNA was used for RT-PCR. The PCR amplification was performed with transcript specific primers (Additional file S1).

\section{Animal studies}

Male WNIN rats (aged 5-6 weeks), normal pellet diet and high fat diets were obtained from National Institute of Nutrition (NIN), Hyderabad, India. After one-week acclimatization period, rats were fed with either normal diet or HFD, water ad-libitum and maintained at standard laboratory conditions (temperature: $23^{\circ} \mathrm{C} \pm 2^{\circ} \mathrm{C}$; humidity: $40-60 \%$ ) for 18 weeks as described in experimental design. Among different types of HFDs used to induce obesity, a HFD with $60 \%$ calories from fat induces obesity most effectively comparable to western diet $[21,22]$. Animals were fed on $20 \%$ protein diet (normal pellet diet) 
(low fat control diet, percent of energy from carbohydrate-64\%, protein-20\% and fat- $16 \%$ ) (Additional file S2) or high fat diet (percent of energy from carbohydrate-20\%, protein-20\% and fat-60\%) (Additional file S3) contained all the recommended macro and micronutrients. To test the therapeutic activity of BSTN1, $1.25,2.5$ and $5 \mathrm{mg} / \mathrm{kg}$ b.wt. of BSTN1 was suspended in $0.5 \%$ carboxymethylcellulose (CMC) and orally administered for 6 weeks from 13th week onwards using an intra-gastric tube. We selected these concentrations based on our initial pilot studies using solvent extracts [12].

IAEC approval (No:55/2012/(i)/a/CPCSEA/IAEC/SVU/MBJ, dated: 8-7-2012) were followed to conduct the animal experiments.

\section{Experimental design}

Rats initially weighing $160-180 \mathrm{~g}$ were randomly divided into six groups of six each $(n=6)$.

Group I: Normal pellet diet fed rats

Group II: HFD-fed rats (Placebo)

Group III: HFD fed + BSTN1 (1.25 mg/kg. b.wt./day) treated rats

Group IV: HFD fed + BSTN1 (2.5 mg/kg. b.wt./day) treated rats

Group V: HFD fed + BSTN1 (5 mg/kg. b.wt./day) treated rats

Group Vl: HFD fed + Orlistat (5 mg/kg. b.wt./day) treated rats

\section{Measurement of body weight and body composition parameters}

The body composition, body weight, fat percent of each rat was measured by Total Body Electrical Conductivity (TOBEC) using a small animal body composition analysis system (EM-SCAN, Model SA3000 Multi detector, Springfield, USA). At the end of the experiment, animals were anesthetized using isoflurane, blood was collected by heart puncture method. Plasma and/or serum were separated by centrifugation at $2500 \mathrm{rpm}$ for $15 \mathrm{~min}$. Various organs and tissues including abdominal adipose tissue and liver were dissected, and stored appropriately. For histology studies tissues were fixed and processed as described in later sections.

\section{Plasma leptin and adiponectin levels}

Plasma leptin and adiponectin are key adipokines secreted by adipocytes. Adipokine levels were measured in experimental rats using enzyme-linked immunosorbent assay kits (Crystal Chem, Downers Grove, IL, USA). These assays were performed in duplicates $(n=6)$, as per the manufacturer's guidelines and adipokine levels were expressed in $\mathrm{ng} / \mathrm{mL}$ [23].

\section{Estimation of serum lipid profile}

Serum total cholesterol (TC) was estimated by CHOD-PAP method, triglycerides (TGs) was estimated by GPO-TOPS method, HDL-cholesterol, VLDL-cholesterol, LDL-cholesterol were estimated by selective 
inhibition method (Agappe Diagnostics Ltd., Kerala, India), phospholipids (PLs) and free fatty acids (FFAs) were assessed as previously described [24].

\section{Estimation of hepatic lipid levels}

Lipids were extracted from the livers of experimental animals as described [25]. In brief, the tissues were rinsed with ice-cold physiological saline, homogenized in cold chloroform-methanol $(2: 1, \mathrm{v} / \mathrm{v})$ and the contents were extracted for $24 \mathrm{~h}$. The extraction was repeated four times. The combined filtrate was washed with $0.7 \%$ potassium chloride and the aqueous layer was discarded. The organic layer was made up to a known volume with chloroform and used for hepatic lipid analysis.

\section{Measurement of AST and ALT activities}

Hepatic marker enzymes, aspartate transaminase (AST) and alanine transaminase (ALT) activities were estimated at the end of the experiment by using commercially available kit (Agappe Diagnostics Ltd, Kerala, India) following the manufacturer's protocol.

\section{Western blot analysis}

Adipose and hepatic tissue proteins were extracted with lysis buffer (Sigma Aldrich, USA) and quantified using Bradford method [26]. Equal amount of protein $(40 \mu \mathrm{g})$ was resolved on 10\% SDS-PAGE gel and transferred onto a nitrocellulose membrane. To block non-specific binding sites, blots were incubated at room temperature with $5 \%$ skimmed milk $(\mathrm{v} / \mathrm{v})$ for $1 \mathrm{~h}$ followed by overnight incubation with primary antibodies of anti-PPAR- $y$, anti-AMPK and mouse anti- $\beta$ actin (1:1,000 dilution, ABclonal Technology, USA) at $4^{\circ} \mathrm{C}$. The immuno-reactive antigen was then recognized by incubation with HRP-conjugated secondary antibody (1:1,000 dilution, Abclonal Technology, USA). Immuno-reactive bands were visualized using chemiluminescence detection system.

\section{Histopathological examination}

Adipose and liver tissues were collected from both control and experimental rats and fixed in formalin solution. A small piece of tissue was cut, trimmed, processed and prepared paraffin blocks. Then the paraffin blocks were sectioned (5-8 $\mu \mathrm{m})$ using microtome and stained using haematoxylin and eosin (H\&E) following standard histology protocol [27].

\section{Molecular docking studies (Accession of target protein)}

The three-dimensional structure of FAS (6NNA), AMPK (6C9F), PPAR-y (3WMH) and BSTN1 were downloaded from the RCSB protein Data Bank and Pub chem. The atomic coordinates of the ligand were geometrically optimized using Argus Lab 4.0.1. [28]. In-silico studies were carried against FAS (6NNA), AMPK (6C9F) and PPAR-y (3WMH), with ligand (BSTN1) using the docking program Patchdock [29]. After the docking, protein-ligand complexes were studied using PyMol viewer tool (www.pymol.org)1. Protein and ligand interactions were analysed and visualized through PyMol viewer tool (www.pymol.org)1.

\section{Statistical analysis}

The results are expressed as the mean \pm standard deviation (SD), and comparison was made by using one-way ANOVA programme followed by Tukey's post hoc tests to study the significance level (SPSS, 
version 17.0; SPSS Inc., Chicago, IL, USA).

\section{Results}

\section{LC-MS \& HPLC analysis}

The chloroform fraction of ethanolic extract of B. purpurea was subjected to LC-MS analysis. Seventeen compounds were identified from which BSTN1 (m.wt.: 283.0496) was isolated, purified and confirmed by HPLC (Figs. 1A-1C).

\section{Cytotoxicity studies by MTT assay}

The effect of BSTN1 on cell viability of 3T3-L1 cells and cytotoxicity was analysed at $48 \mathrm{~h}$ using MTT assay. BSTN1 showed IC50 value of $118 \mu \mathrm{M}$ in the dose range of $10-160 \mu \mathrm{M}$, dose was optimized to less than $10 \%$ for further in-vitro analyses (Fig. 2D).

\section{Effect of BSTN1 on adipogenesis and lipid content}

BSTN1 at $20 \mu \mathrm{M}$ markedly reduced adipogenesis and intracellular lipid levels of 3T3-L1 cells, as observed by Oil-Red-O-stained images (Fig. 2A). We further quantified the lipid content by extracting the (using isopropanol) Oil-Red-O stain from 3T3-L1 adipocytes (Fig. 2B). To complement these studies, we verified the lipolytic capacity of BSTN1 by quantifying the levels of glycerol release from treated versus control and vehicle control 3T3-L1 adipocytes. Significantly high level of glycerol release was observed in adipocytes treated with BSTN1 than untreated cells and the maximum lipolytic activity was noticed at a concentration of $20 \mu \mathrm{M}$ (Fig. 2C).

\section{mRNA expression (RT-PCR) studies}

The mRNA expression levels of key adipogenic transcriptional and lipogenic factors, FAS, SREBP1, AMPK and PPAR- $\gamma$ in differentiated 3T3-L1 adipocytes were estimated in the absence and presence of BSTN1 (5, 10 and $20 \mu \mathrm{M}$ ) (Fig. 3). The expression of FAS, SREBP1 and PPAR-y were down-regulated, while AMPK was up-regulated with increasing concentration of BSTN1 as represented in Figs. 3A to 3D.

\section{Adipogenic and lipogenic protein markers expression in adipose and hepatic tissues}

Figure 4 shows the protein expression levels of AMPK and PPAR-y in hepatic and adipose tissues of placebo and obese-treated rats. BSTN1 treated obese rats showed significant alteration in the key adipogenic and energy homeostasis proteins, PPAR- $y$ and AMPK respectively. The expression of these proteins was normalized to house-keeping gene $\beta$-actin. BSTN1 mediated normalized levels of AMPK and PPAR-y proteins could reduce the fat accumulation in liver and adipose tissues, reduce non-alcoholic fatty liver disease and lead obesity ailments.

\section{Body composition and body weight of obese rats}

Table 1 depicts the changes in body weight and body composition of experimental rats. Consumption of HFD for 18 weeks resulted in significant changes in body weights $(486 \pm 9.0 \mathrm{~g})$ and total body fat levels (79 $\pm 7.8 \mathrm{~g})$ in HFD control group, compared to normal control group of rats whose body weight and total 
fat were $248.1 \pm 6.3 \mathrm{~g}$ and $10.2 \pm 1.4 \mathrm{~g}$, respectively. Oral administration of BSTN1 $(1.25,2.5 \mathrm{and} 5 \mathrm{mg} / \mathrm{kg}$. b.wt.) for 6 weeks (from 13 to 18 weeks) considerably reduced body weight gain and body composition parameters in a dose dependent manner with maximum reduction (in body weight $320 \pm 13.9 \mathrm{~g}$ and total fat levels $24.9 \pm 1.9 \mathrm{~g}$ ) being noted in rats treated with $5 \mathrm{mg} / \mathrm{kg}$. b.wt. of BSTN1.

Table 1

Effect of BSTN1 on body weight and body composition parameters of treated and untreated rats.

\begin{tabular}{|c|c|c|c|c|c|c|}
\hline Parameters & $\begin{array}{l}\text { Normal } \\
\text { control }\end{array}$ & $\begin{array}{l}\text { HFD } \\
\text { control }\end{array}$ & $\begin{array}{l}\text { BSTN1- } \\
1.25 \mathrm{mg}\end{array}$ & $\begin{array}{l}\text { BSTN1-2.5 } \\
\mathrm{mg}\end{array}$ & $\begin{array}{l}\text { BSTN1-5 } \\
\text { mg }\end{array}$ & ORL-5 mg \\
\hline $\begin{array}{l}\text { Initial body } \\
\text { weight (g) }\end{array}$ & $\begin{array}{l}168.3 \pm \\
7.0\end{array}$ & $\begin{array}{l}182.5 \pm \\
9.4\end{array}$ & $177.3 \pm 8.4$ & $\begin{array}{l}179.3 \pm \\
10.7\end{array}$ & $183.2 \pm 8.0$ & $180.8 \pm 5.9$ \\
\hline $\begin{array}{l}\text { Final body } \\
\text { weight (g) }\end{array}$ & $\begin{array}{l}248.1 \pm \\
6.3\end{array}$ & $\begin{array}{l}486.3 \pm \\
9.0^{\#}\end{array}$ & $\begin{array}{l}445.2 \pm \\
11.0^{*}\end{array}$ & $\begin{array}{l}401.5 \pm \\
12.0^{* \star}\end{array}$ & $\begin{array}{l}320.5 \pm \\
13.9^{\star \star \star}\end{array}$ & $\begin{array}{l}312.7 \pm \\
7.7^{\star \star \star}\end{array}$ \\
\hline $\begin{array}{l}\text { Body weight } \\
\text { gain }(\mathrm{g})\end{array}$ & $79.8 \pm 4.6$ & $\begin{array}{l}303.8 \pm \\
15.5^{\#}\end{array}$ & $\begin{array}{l}267.8 \pm \\
10.7^{*}\end{array}$ & $\begin{array}{l}222.2 \pm \\
14.8^{\star \star}\end{array}$ & $\begin{array}{l}137.3 \pm \\
17.8^{\star \star \star}\end{array}$ & $\begin{array}{l}131.8 \pm \\
10.7^{\star \star \star}\end{array}$ \\
\hline $\begin{array}{l}\text { Lean body } \\
\text { mass }(\mathrm{g})\end{array}$ & $\begin{array}{l}237.9 \pm \\
7.0\end{array}$ & $\begin{array}{l}407.3 \pm \\
7.8^{\#}\end{array}$ & $\begin{array}{l}382.6 \pm \\
13.6^{*}\end{array}$ & $\begin{array}{l}358.6 \pm \\
14.2^{\star \star}\end{array}$ & $\begin{array}{l}295.7 \pm \\
14.4^{\star \star \star}\end{array}$ & $\begin{array}{l}290.1 \pm \\
6.5^{\star \star \star}\end{array}$ \\
\hline $\begin{array}{l}\text { Total body fat } \\
\text { (g) }\end{array}$ & $10.2 \pm 1.4$ & $79 \pm 7.8^{\#}$ & $62.5 \pm 3.8^{*}$ & $42.9 \pm 2.4^{\star \star}$ & $24.9 \pm 1.9^{\star \star \star}$ & $\begin{array}{l}22.6 \pm \\
4.6^{\star \star \star}\end{array}$ \\
\hline Body fat (\%) & $4.1 \pm 0.6$ & $\begin{array}{l}16.2 \pm \\
1.5^{\#}\end{array}$ & $14.1 \pm 1.1^{*}$ & $10.7 \pm 0.9^{\star *}$ & $7.8 \pm 0.7^{\star \star \star}$ & $7.2 \pm 1.4^{\star \star \star}$ \\
\hline $\begin{array}{l}\text { Fat free mass } \\
\text { (g) }\end{array}$ & $\begin{array}{l}147.1 \pm \\
4.1\end{array}$ & $\begin{array}{l}225.4 \pm \\
5.3^{\#}\end{array}$ & $\begin{array}{l}215.5 \pm \\
8.3^{*}\end{array}$ & $\begin{array}{l}206.8 \pm \\
8.5^{\star \star}\end{array}$ & $\begin{array}{l}175.9 \pm \\
8.3^{\star \star \star}\end{array}$ & $\begin{array}{l}173.3 \pm \\
3.9^{\star \star \star}\end{array}$ \\
\hline $\begin{array}{l}\text { Total body } \\
\text { water }\end{array}$ & $\begin{array}{l}620.1 \pm \\
18.5\end{array}$ & $\begin{array}{l}972.6 \pm \\
23.9^{\#}\end{array}$ & $\begin{array}{l}928.2 \pm \\
37.4^{*}\end{array}$ & $\begin{array}{l}888.9 \pm \\
38.3^{* \star}\end{array}$ & $\begin{array}{l}749.7 \pm \\
37.2^{\star \star \star}\end{array}$ & $\begin{array}{l}738 \pm \\
17.4^{\star \star \star}\end{array}$ \\
\hline Total body $\mathrm{Na}+$ & $\begin{array}{l}859.4 \pm \\
25.7\end{array}$ & $\begin{array}{l}1349 \pm \\
33.1^{\#}\end{array}$ & $\begin{array}{l}1287.3 \pm \\
52.0^{*}\end{array}$ & $\begin{array}{l}1232.7 \pm \\
53.2^{\star \star}\end{array}$ & $\begin{array}{l}1039.4 \pm \\
51.7^{\star \star \star}\end{array}$ & $\begin{array}{l}1023.2 \pm \\
24.2^{\star \star \star}\end{array}$ \\
\hline Total body K+ & $\begin{array}{l}1783.1 \pm \\
51.0\end{array}$ & $\begin{array}{l}2752.4 \pm \\
65.6^{\#}\end{array}$ & $\begin{array}{l}2630.3 \pm \\
103.0^{*}\end{array}$ & $\begin{array}{l}2522.3 \pm \\
105.4^{\star \star}\end{array}$ & $\begin{array}{l}2139.5 \pm \\
102.3^{\star \star \star}\end{array}$ & $\begin{array}{l}2107.3 \pm \\
48.0^{\star \star \star}\end{array}$ \\
\hline
\end{tabular}


Table 2

Effect of BSTN1 on serum lipid profile of treated and untreated rats.

\begin{tabular}{|c|c|c|c|c|c|c|}
\hline Parameters & $\begin{array}{l}\text { Normal } \\
\text { control }\end{array}$ & $\begin{array}{l}\text { HFD } \\
\text { control }\end{array}$ & $\begin{array}{l}\text { BSTN1-1.25 } \\
\text { mg }\end{array}$ & $\begin{array}{l}\text { BSTN1-2.5 } \\
\mathrm{mg}\end{array}$ & $\begin{array}{l}\text { BSTN1-5 } \\
\text { mg }\end{array}$ & ORL-5mg \\
\hline $\mathrm{TC}(\mathrm{mg} / \mathrm{dL})$ & $84.0 \pm 4.1$ & $\begin{array}{l}114.5 \pm \\
13.2^{\#}\end{array}$ & $98.4 \pm 9.4^{*}$ & $92.3 \pm 9.3^{\star \star}$ & $\begin{array}{l}82.3 \pm \\
14.3^{\star \star \star}\end{array}$ & $\begin{array}{l}75.6 \pm \\
15.3^{\star \star \star}\end{array}$ \\
\hline $\begin{array}{l}\text { TGL } \\
(\mathrm{mg} / \mathrm{dL})\end{array}$ & $148.9 \pm 9.4$ & $\begin{array}{l}185.9 \pm \\
8.7^{\#}\end{array}$ & $173.7 \pm 6.4^{*}$ & $\begin{array}{l}160.3 \pm \\
6.6^{\star \star}\end{array}$ & $\begin{array}{l}137.2 \pm \\
8.6^{\star \star \star}\end{array}$ & $\begin{array}{l}131.0 \pm \\
9.2^{\star \star \star}\end{array}$ \\
\hline $\begin{array}{l}\mathrm{HDL} \\
(\mathrm{mg} / \mathrm{dL})\end{array}$ & $45.8 \pm 11.6$ & $\begin{array}{l}27.9 \pm \\
10.5^{\#}\end{array}$ & $31.7 \pm 12.9^{\star}$ & $\begin{array}{l}39.5 \pm \\
13.5^{\star \star}\end{array}$ & $\begin{array}{l}41.5 \pm \\
10.1^{\star \star \star}\end{array}$ & $\begin{array}{l}44.1 \pm \\
13.9^{\star \star \star}\end{array}$ \\
\hline $\begin{array}{l}\mathrm{LDL} \\
(\mathrm{mg} / \mathrm{dL})\end{array}$ & $62.8 \pm 1.9$ & $84.2 \pm 1.7^{\#}$ & $76.7 \pm 1.3^{*}$ & $71.1 \pm 1.3^{* *}$ & $\begin{array}{l}54.4 \pm \\
1.7^{\star \star \star}\end{array}$ & $\begin{array}{l}43.4 \pm \\
1.8^{\star \star \star}\end{array}$ \\
\hline $\begin{array}{l}\text { VLDL } \\
(\mathrm{mg} / \mathrm{dL})\end{array}$ & $12.4 \pm 15.8$ & $\begin{array}{l}29.4 \pm \\
21.7^{\#}\end{array}$ & $21.0 \pm 12.6^{*}$ & $17.8 \pm 8.1^{\star \star}$ & $\begin{array}{l}13.4 \pm \\
13.9^{\star \star \star}\end{array}$ & $\begin{array}{l}9.0 \pm \\
12.8^{\star \star \star}\end{array}$ \\
\hline $\begin{array}{l}\text { PLs } \\
\text { (mg/dL) }\end{array}$ & $57.1 \pm 3.2$ & $\begin{array}{l}112.7 \pm \\
7.6^{\#}\end{array}$ & $101.4 \pm 12.1^{*}$ & $84.3 \pm 3.7^{\star \star}$ & $\begin{array}{l}63.4 \pm \\
11.0^{\text {* }}\end{array}$ & $\begin{array}{l}61.7 \pm \\
6.2^{\star *}\end{array}$ \\
\hline $\begin{array}{l}\text { FFA } \\
(\mathrm{mg} / \mathrm{dL})\end{array}$ & $46.7 \pm 2.2$ & $96.3 \pm 9.6^{\#}$ & $87.4 \pm 11.7^{\star}$ & $64.1 \pm 9.4^{\star \star}$ & $\begin{array}{l}50.5 \pm \\
15.7^{\star \star \star}\end{array}$ & $\begin{array}{l}44.7 \pm \\
8.7^{\star \star \star}\end{array}$ \\
\hline
\end{tabular}

\section{Effect of BSTN1 on leptin and adiponectin levels and adipose tissue architecture}

Figure 5 shows the systemic levels of leptin and adiponectin in control and experimental obese rats. We observed markedly elevated levels of plasma leptin but decrease in adiponectin levels in HFD fed rats, when compared to the normal rats. Interestingly, treatment with BSTN1 has significantly $(p<0.01)$ decreased leptin levels, while the levels of adiponectin were increased. The H\&E-stained adipose tissue sections of control rats showed the normal adipocyte structure (Fig. 5B). In contrast, adipocytes of HFDinduced obese rats are significantly larger (Fig. 5C) (hypertrophy) with indistinct cell walls compared to adipocytes of control rats. Relatively smaller sized adipocytes were visualized in BSTN1 treated rats indicating reduced lipid droplets, and this effect was more significant than even orlistat treated group (Figs. 5D and 5E).

\section{Effect of BSTN1 on hepatic enzymes (AST and ALT) and hepatic tissue architecture}

Figure 6 depicts the activities of aspartate transaminase (AST) and alanine transaminase (ALT) in control and experimental obese rats. Administration of BSTN1 (1.25, 2.5 and $5 \mathrm{mg} / \mathrm{kg}$. b.wt.) markedly reduced AST and ALT levels $(p<0.01)$ in dose dependent manner when compared to HFD control rats. Hepatic tissues of untreated and treated rats were sectioned, stained with H\&E staining that represents normal hepatic structure made up of healthy hepatic lobules and a central vein possessing radiating strands in untreated rats (Fig. 6B). But an accumulated lipid content around the central vein and in between the 
hepatocytes lead to inflated and disruption of lobules were seen in obese rats (Fig. 6C). Interestingly, the liver sections from obese rats treated with BSTN1 (Fig. 6D) were seem to be better/equally recovered than that of Orlistat treated group (Fig. 6E). However, central veins were found to be a little dilated in BSTN1 groups than normal but cells as such were found to be healthy.

\section{Effect of BSTN1 on serum and liver lipid profiles}

The HFD-induced obese rats exhibited significant alterations in serum and liver lipid levels (over their respective control rats). Treatment with BSTN1 (1.25, 2.5 and $5 \mathrm{mg} / \mathrm{kg}$. b.wt.) had significantly normalized the altered levels of serum total cholesterol (TC), triglycerides (TGL), high-density lipoprotein $(H D L)$, low-density lipoprotein (LDL), very low-density lipoproteins (VLDL), phospholipids (PLs) and free fatty acids (FFA) (Table-2). Similarly, the liver tissue lipids including total cholesterol (TC), triglycerides (TGL) and free fatty acids (FFA) were also markedly normalized in the presence of BSTN1 (Table 3).

Table 3

Effect of BSTN1 on hepatic lipid profile of treated and untreated rats.

\begin{tabular}{|c|c|c|c|c|c|c|}
\hline Parameters & $\begin{array}{l}\text { Normal } \\
\text { control }\end{array}$ & $\begin{array}{l}\text { HFD } \\
\text { control }\end{array}$ & $\begin{array}{l}\text { BSTN1-1.25 } \\
\text { mg }\end{array}$ & $\begin{array}{l}\text { BSTN1-2.5 } \\
\mathrm{mg}\end{array}$ & $\begin{array}{l}\text { BSTN1-5 } \\
\text { mg }\end{array}$ & ORL-5mg \\
\hline $\begin{array}{l}\mathrm{TC} \\
(\mathrm{mg} / \mathrm{dL})\end{array}$ & $61.37 \pm 5.3$ & $\begin{array}{l}118.2 \pm \\
7.4^{\#}\end{array}$ & $111.6 \pm 12.2^{*}$ & $91.3 \pm 11.0^{\star \star}$ & $\begin{array}{l}67.6 \pm \\
8.0^{\star \star \star}\end{array}$ & $\begin{array}{l}62.9 \pm \\
7.5^{\star \star \star}\end{array}$ \\
\hline $\begin{array}{l}\mathrm{TGL} \\
(\mathrm{mg} / \mathrm{dL})\end{array}$ & $84.9 \pm 2.7$ & $\begin{array}{l}156.1 \pm \\
7.7^{\#}\end{array}$ & $127.7 \pm 1.3^{*}$ & $97.8 \pm 2.5^{\star \star}$ & $\begin{array}{l}79.07 \pm \\
1.7^{\star \star \star}\end{array}$ & $\begin{array}{l}81.6 \pm \\
2.1^{\star \star \star}\end{array}$ \\
\hline FFA (mg/g) & $69.34 \pm 3.0$ & $\begin{array}{l}125.8 \pm \\
2.3^{\#}\end{array}$ & $104.9 \pm 3.0^{*}$ & $84.1 \pm 2.3^{\star \star}$ & $\begin{array}{l}70.3 \pm \\
2.7^{\star \star \star}\end{array}$ & $\begin{array}{l}62.3 \pm \\
2.1^{\star \star \star}\end{array}$ \\
\hline
\end{tabular}

\section{In-silico molecular docking}

The outcome of the docking studies indicated that BSTN1 interacts with FAS (6NNA) with - 100 binding energy. Consequently, the results showed that BSTN1 binds to FAS at the fatty acid binding site (substrate binding cleft), at amino acid residues His1263, Asn1458, Arg1461 and Arg14622 through multiple hydrogen $(\mathrm{H})$ bonds. In addition, the site at which BSTN1 binds to the enzyme is very similar to that of the binding site for NADP and ethane diol, which suggests a stronger regulatory position for BSTN1 (Figs. 7A-7C). Docking studies predict that BSTN1 binds to AMPK by $\mathrm{H}$-bonds close to the adenosine monophosphate (AMP) binding site with a binging energy of - 148.62 (Figs. 7D-7F). But, close to the recognized inhibitor (JAA) binding location, BSTN1 interacts strongly with PPAR- $y$ with a binging energy of - 194.0. Three $\mathrm{H}$-bond interactions $(-\mathrm{OH}$ group of Tyrosine, $-\mathrm{OH}$ group of Serine, $-\mathrm{NH}$ group of Histidine) were observed between PPAR-y and Bauhiniastatin-1 (Figs. 7G-7I) (Table 4). 
Table 4

Molecular docking of BSTN1 (11687814) ligand-protein binding interactions.

\begin{tabular}{|c|c|c|c|c|}
\hline Ligand & Proteins & $\begin{array}{l}\text { Binding } \\
\text { Energy }\end{array}$ & $\begin{array}{l}\text { Bond } \\
\text { Length }(\AA)\end{array}$ & Bonding Interaction \\
\hline \multirow{8}{*}{$\begin{array}{l}\text { Bauhiniastatin- } \\
1 \\
\text { (BSTN1) }\end{array}$} & \multirow{4}{*}{$\begin{array}{l}\text { PPAR-Y } \\
\text { (3WMH) }\end{array}$} & \multirow[t]{4}{*}{-194.0} & \multirow[t]{4}{*}{$2.3-3$} & $\mathrm{H}$-bond interaction \\
\hline & & & & (-OH group of Tyrosine (Tyr327), \\
\hline & & & & JJA - OH group of Serine (Ser289) \\
\hline & & & & -NH group of Histidine (His449)) \\
\hline & \multirow{2}{*}{$\begin{array}{l}\text { AMPK } \\
(6 C 9 F)\end{array}$} & \multirow[t]{2}{*}{-148.62} & \multirow[t]{2}{*}{$3-3.3$} & $\mathrm{H}$-bond interaction \\
\hline & & & & $\begin{array}{l}\text { (AMP binding site - Thr86, Val127 } \\
\text { and Pro129) }\end{array}$ \\
\hline & \multirow[t]{2}{*}{ FAS (6NNA) } & \multirow[t]{2}{*}{-100.0} & \multirow[t]{2}{*}{$3-3.6$} & $\mathrm{H}$-bond interaction \\
\hline & & & & $\begin{array}{l}\text { (His1263, Asn1458, Arg1461 and } \\
\text { Arg14622) }\end{array}$ \\
\hline
\end{tabular}

\section{Discussion}

In the present study, Bauhiniastatin-1, an oxepin derivative was isolated and purified from Bauhinia purpurea and evaluated for its anti-obesity and anti-NAFLD efficacy. Accumulation of lipid droplets in adipocytes plays a central role in the growth and hypertrophy of adipose tissue. For the prevention and management of obesity, inhibition of adipocyte differentiation and promotion of glycerol release by breakdown of triglycerides present in adipocytes is therefore essential [30]. Activated AMPK attenuates lipid accumulation during adipogenesis by inhibiting the expression of PPARY, C/EBPa, SREBP1 and FAS [31]. AMPK also plays a critical role in regulating hepatic lipid metabolism, glucose transport and gluconeogenesis, hence, AMPK may also be considered as a target for the treatment of obesity and NAFLD [32]. In this study, as evident from the Oil Red 0 stain and glycerol estimation assay, the purified BSTN1 showed substantial inhibition of adipogenesis and lipid accumulation in 3T3-L1 cells compared to untreated cells (Figs. 2A-2C). With BSTN1 treated adipocytes, down-regulation of gene expression of PPARY, SREBP1 and FAS and up-regulation of AMPK was observed, indicating their role in energy homeostasis, attenuating adipogenesis and lipogenesis (Figs. 3A-3D). PPARy consists of DNA binding domain, agonist-dependent- and agonist-independent-activation domain expressed ubiquitously but abundantly in adipocytes [33]. PPARY activates fatty acid uptake leading to neutral lipid accumulation in adipocytes [34] and sufficient for adipogenic induction [35,36] making it a master regulator of adipogenesis. PPARY sensitizers, thiozolidinediones, induce adipocyte differentiation $[37,38]$ but improve glycemic control, insulin sensitivity and $\beta$-cell function implicating PPARY's role in metabolic regulation $[39,40]$. Overall, PPARYs are important transcriptional factors that play a central role in glucose homeostasis, fatty acid synthesis and adipogenesis [41]. Obese condition leads to insulin resistance 
which causes activation of PPAR- $y$ and triggers glucose transporters (Glut-2) in liver that favour glucose uptake by hepatocytes and synthesis of triacylglycerols (TAGs) in liver ultimately leading to the pathogenesis of NAFLD $[42,43]$. However, in our studies, BSTN1 down regulated PPARy thus, might reduce ectopic fat accumulation in hepatic tissue and prevents non-alcoholic fatty liver condition.

In animal experiments we did analysis of body composition parameters. A substantially reduced body weight gain and total fat mass was noticed with BSTN1 treated rats over their HFD controls. Biochemical assays of serum AST, ALT, serum and liver lipid and plasma adipokine profiles indicated the therapeutic role of BSTN1 in attenuating HFD induced alterations in rats. Adipokines are adipose tissue-derived bioactive molecules that play important role in human health or disease. Leptin and adiponectin might promote lipolysis, fatty acid oxidation and inhibit lipogenesis in liver and adipose tissue through AMPK activation $[44,45,46]$. AMPK gets activated through phosphorylation of a conserved threonine in the activation loop of kinase domain in the a subunit $[47,48]$ or binding of AMP that can be mimicked by ADP and can be antagonized by ATP [49]. Many of the AMPK activators including natural plant derived therapeutics like resveratrol and berberine activate AMPK by indirectly inhibiting ATP levels through increasing AMP and/or ADP [50, 51, 52].

Histological examination of liver and adipose tissue micrographs clearly demonstrated the antiadipogenic and anti-lipogenic or pro-lipolytic effect of BSTN1 (Figs. 5 and 6). Western blot and RT-PCR analysis of liver and adipose tissue showed down regulated expression of PPAR-y but up-regulation of AMPK in BSTN1 treated groups confirming anti-adipogenic and anti-lipogenic roles of BSTN1 (Figs. 3 and 4). This is in agreement with the fact that, when AMPK is activated, it diminishes the expression of C/EBPa, PPARY, SREBP1 and acyl-CoA carboxylase (ACC) in adipose and hepatic tissues and thus inhibits synthesis of fatty acids and triglycerides [53]. Green tea extract, capsaicin, guggulsterone, genistein and piperine were shown to regulate glucose homeostasis and fatty acid synthesis in liver as well as adipogenesis in adipose tissue through PPARY and AMPK mediated signaling [54].

Binding of BSTN1 against PPAR-y and AMPK showed favourable binding interaction compared to FAS and other adipogenic pathway transcriptional factors that we tested, demonstrating them as possible targets for BSTN1 to attenuate NAFLD, adipogenesis and obesity. Our docking studies also suggest that BSTN1 binds AMPK at the AMP binding site through hydrogen bonding with Thr86 and two other residues, Val127 and Pro129. BSTN1 binding with Thr86 implicates that BSTN1 potentially activates AMPK function as well as expression through the interactions or vice versa.

In addition to the observed effects of BSTN1 on PPAR- $y$ gene expression changes at transcriptional and translation levels, our receptor-ligand docking studies further demonstrate that BSTN1 binds to PPAR- $Y$ mediated by hydrogen bonding with amino acids Ser289, Tyr327 and His449. Previously MEKT75, a partial agonist of PPAR- $\gamma$ (3WMH/JJA, N-(phenlysulfonyl)-4-propoxy-3-(\{[4-(pyrimidin-2yl)benzoyl]amino\}methyl)benzamide), was shown to interact at positions His266, Tyr327, His449 of PPAR-y to inhibit its function. Instead of His266 another amino acid close to this Ser289 interacting with BSTN1 in the binding site of JJA agonist in addition to the binding of amino acids, Tyr327 and His449. 
MEKT75 show similar scaffold like MEKT-21 and 9i (antagonist), implicating direct inhibitory activity of BSTN1 on PPAR- $\gamma$ function [55]. The observed reduction of PPAR-y expression could be in part due to these interactions initiating negative feedback loop. In addition, potential binding prediction of BSTN1 with FAS indicates the inhibitory function of BSTN1 on FAS as well. BSNT1 binding at fatty acid binding site of FAS seem to be very interesting, but the lower negative energy of these interaction warrants to further investigate these enzyme substrate/inhibitor interactions.

Our studies further demonstrate that BSTN1 binds to AMPK near the adenosine monophosphate (AMP) binding site there by potentially mimicking AMP to activate AMPK. However, the binding of BSTN1 to the AMPK and PPAR-y proteins seems to have positive and negative regulatory action on the transcription of AMPK and/or PPAR-y respectively. Additionally, 5-aminoimidazole-4-carboxamide riboside (AMPK activator) mediated activation of AMPK was shown to inhibit PPAR-y and PPAR-a which may not be mediated through RXR or PPAR/RXR binding to DNA implicating potential multiple level regulation of BSTN1 on PPAR-y [56]. This suggests complex agonist/antagonist binding dynamics with AMPK and PPAR-y explaining BSTN1 binding to these two key proteins.

MTT assay showed non-significant reduction in 3T3-L1 cell viability up to 48 hours, however the observed anti-adipogenic functions in our studies might also be partially due to additional BSTN1 mediated adipocyte specific apoptotic pathway regulation as observed in Oil-Red-0 stain photomicrographs. Cell viability (in vitro assays), histology studies and hepatic health markers status indicate the safety of BSTN1.

\section{Conclusions}

In this study, both in vivo and in vitro studies have clearly demonstrated the therapeutic efficacy of BSTN1 against adipogenesis, obesity and NAFLD via PPAR- $\gamma$ and AMPK modulation. These observations are further complimented and confirmed by molecular docking studies. Therefore, BSTN1 can be considered as a potential therapeutic molecule for managing obesity ailments.

\section{Abbreviations}

Bauhiniastatin-1, BSTN1; AMPK, 5' AMP-activated protein kinase; PPAR-y, peroxisome proliferatoractivated receptor- $\gamma$, SREBP1, sterol regulatory element-binding protein 1; FAS, fatty acid synthase; AST, aspartate transaminase; ALT, alanine aminotransferase; NAFLD, non-alcoholic fatty liver disease; DMEM, Dulbecco's Modified Eagle's medium; FBS, fetal bovine serum; MDI, differentiation medium of Induction; HFD, High-fat diet; IBMX, 3isobutyl1methyl xanthine; MTT, (3-(4,5-dimethylthiazol-2-yl)-2,5-diphenyl tetrazolium bromide).

\section{Declarations}

\section{Ethics approval and consent to participate}


This study was approved by the Institutional Animal Ethical Committee of Sri Venkateswara University. The institutional review board approved this procedure.

\section{Consent for publication}

All authors revised the data and approved the manuscript being submitted. And we have not used any third parties' data.

\section{Availability of data and materials}

The analyzed and/or used datasets presented herein are available from the corresponding author upon reasonable request.

\section{Competing interests}

No competing interests among all the authors.

\section{Funding}

This work was supported by the Indian Council of Medical Research, Govt. of India, New Delhi. [grant number: 59/25/2011/BMS/TRM, dated: 23-03-2015].

\section{Authors' Contributions}

Appa Rao Ch, Kameswara Rao B and Balaji M conceived and developed the idea. Karunakaran RS and Venkataramaiah Ch did isolation and purification of Bauhiniastatin-1. Karunakaran RS, Lokanatha O, and Muni Swamy G conducted experiments (cell culture and animal studies). Muni Kesavulu M, Kameswara B and Venkataramaiah Ch conducted the molecular modelling studies. Karunakaran RS, Muni Swamy G, Lokanatha $\mathrm{O}$ and Balaji $\mathrm{M}$ collected the data and performed statistical analysis. Karunakaran RS, Muni Swamy M, Appa Rao C, Kameswara Rao B and Balaji M analysed data and/or interpreted the results. Muni Kesavulu M, Kameswara Rao B and Balaji M wrote the manuscript.

\section{Acknowledgements}

The authors thank and acknowledge Dr. K. Suresh Babu, Principal Scientist, Indian Institute of Chemical Technology, Hyderabad, for supporting isolation and purification of phytoconstituents; Dr. P. Suresh, Dr. N. Harishankar, Dr. K. Rajender Rao, Dr. R. Ravindar Naik and Dr. M. Sathyavani, National Institute of Nutrition, Hyderabad, India for supporting animal research experiments.

\section{Authors' information}

${ }^{1}$ Division of Cell Culture and Molecular Biology, Department of Biochemistry, Sri Venkateswara University, Tirupati - 517502, A.P., India. 
2Division of Molecular Biology, Department of Zoology, Sri Venkateswara University, Tirupati - 517502, A.P., India.

${ }^{3}$ Department of Basic Sciences and Humanities, Sree Vidyanikethan Engineering College, Tirupati, India.

${ }^{4}$ Department of Pharmacology \& Toxicology, Cardiovascular Research Institute, Morehouse School of Medicine, Atlanta, GA 30310, USA.

\section{Co-authors E-mail-IDs:}

Karunakaran RS: karunakaranrs.1986@gmail.com

Lokanatha 0: oruganti.loka@gmail.com

Muni Swamy G: muni.gbch@gmail.com

Venkataramaiah Ch: chintharamana9@gmail.com

Muni Kesavulu M: muppurumk@gmail.com

\section{References}

1. Kumar T, Chandrashekar KS. Bauhinia purpurea Linn. A review of its ethnobotany, phytochemical and pharmacological profile. Res J Med Plant. 2011;5:420-31.

2. Sandoval JR. Invasive Species Compendium. CABI, 2019.

3. Zakaria ZA, Wen LY, Abdul-Rahman NI, Abdul-Ayub AH, Sulaiman MR, Gopalan HK. Antinociceptive, anti-inflammatory and antipyretic properties of the aqueous extract of Bauhinia purpurea leaves in experimental animals. Med Princ Pract. 2007;16(6):443-9.

4. Perdomo CM, Fruhbeck G, Escalada J. Impact of nutritional changes on non-alcoholic fatty liver disease. Nutrients. 2019;11(3):677.

5. Perumpail BJ, Khan MA, Yoo ER, Cholankeril G, Kim D, Ahmed A. Clinical epidemiology and disease burden of non-alcoholic fatty liver disease. World J Gastroenterol. 2017;23(47):8263-76.

6. Garcia D, Hellberg K, Chaix A, Wallace M, Herzig S, Badur MG, et al. Genetic liver-specific AMPK activation protects against diet-induced obesity and NAFLD. Cell Rep. 2019;26(1):192-208 e196.

7. Tana C, Ballestri S, Ricci F, Vincenzo AD, Ticinesi A, Gallina S, et al. Cardiovascular risk in nonalcoholic fatty liver disease: mechanisms and therapeutic implications. Int $\mathrm{J}$ Environ Res Public Health. 2019;16(17):3104.

8. Boettler T, Marjot T, Newsome PN, Mondelli MU, Maticic M, Cordero E, et al. Impact of COVID-19 on the care of patients with liver disease: EASL-ESCMID position paper after 6 months of the pandemic. JHEP Reports. 2020;2(5):100169. 
9. Cheng C, Zhuo S, Zhang B, Zhao X, Liu Y, Liao C, et al. Treatment implications of natural compounds targeting lipid metabolism in non-alcoholic fatty liver disease, obesity and cancer. Int J Biol Sci. 2019;15(8):1654-63.

10. Cheng C, Li Z, Zhao X, Liao C, Quan J, Bode AM, et al. Natural alkaloid and polyphenol compounds targeting lipid metabolism: Treatment implications in metabolic diseases. Eur J Pharmacol. 2020;870:172922.

11. Payab M, Ranjbar SH, Shahbal N, Qorbani M, Aletaha A, Haghi-Aminjan H, et al. Effect of the herbal medicines in obesity and metabolic syndrome: A systematic review and meta-analysis of clinical trials. Phytother Res. 2020;34(3):526-45.

12. Padmaja TK, Naidu PB, Hanuma Kumar GEN, Ganapathy S, Balaji M. Anti-obesity activity of Bauhinia purpurea extract: effect on hormones and lipid profile in high calorie diet induced obese rats. Adv Biosc Biotech. 2014;5:861-73.

13. Pettit GR, Numata A, Iwamoto C, Usami Y, Yamada T, Ohishi H, et al. Antineoplastic agents. 551. Isolation and structures of bauhiniastatins 1-4 from Bauhinia purpurea. J Nat Prod. 2006;69(3):323-7.

14. Badri KR, Zhou Y, Dhru U, Aramgam S, Schuger L. Effects of the SANT domain of tensioninduced/inhibited proteins (TIPs), novel partners of the histone acetyltransferase p300, on p300 activity and TIP-6-induced adipogenesis. Mol Cell Biol. 2008;28(20):6358-72.

15. Hsieh CC, Huang YS. Aspirin breaks the crosstalk between 3T3-L1 adipocytes and 4T1 breast cancer cells by regulating cytokine production. PLoS One. 2016;11(1):e0147161.

16. Lee HW, Rhee DK, Kim BO, Pyo S. Inhibitory effect of sinigrin on adipocyte differentiation in 3T3-L1 cells: Involvement of AMPK and MAPK pathways. Biomed Pharmacother. 2018;102:670-80.

17. Varinli H, Osmond-McLeod MJ, Molloy PL, Vallotton P. LipiD-QuanT: a novel method to quantify lipid accumulation in live cells. J Lipid Res. 2015;56(11):2206-16.

18. Nunez S, Young C, Adebayo O, Muppuru KM, Badri KR. P311, a novel intrinsically disordered protein, regulates adipocyte development. Biochem Biophys Res Commun. 2019;515(1):234-40.

19. Shobha CR, Prashant V, Akila P, Chandini R, Suma MN, Basavanagowdappa H. Fifty percent ethanolic extract of Momordica charantia inhibits adipogenesis and promotes adipolysis in 3T3-L1 preadipocyte cells. Rep Biochem Mol Biol. 2017;6(1):22-32.

20. Wan XS, Wang X, Xiao J, Li X, Zhou H. Corrigendum to "ATF4- and CHOP-dependent induction of FGF21 through endoplasmic reticulum stress". Biomed Res Int. 2018;2018:7 pages.

21. Johnston SL, Souter DM, Erwin SS, Tolkamp BJ, Yearsley JM, Gordon IJ, et al. Associations between basal metabolic rate and reproductive performance in C57BL/6J mice. J Exp Biol. 2007;210:65-74.

22. Donovan MJ, Paulino G, Raybould HE. Activation of hindbrain neurons in response to gastrointestinal lipid is attenuated by high fat, high energy diets in mice prone to diet-induced obesity. Brain Res. 2009;1248:136-40.

23. Margoni A, Perrea DN, Vlachos I, Prokopaki G, Pantopoulou A, Fotis L, et al. Serum leptin, adiponectin and tumor necrosis factor-alpha in hyperlipidemic rats with/without concomitant diabetes mellitus. 
Mol Med. 2011;17(1-2):36-40.

24. Meriga B, Parim BN, Chunduri VR, Ravindar Naik R, Harishankar N, Suresh P, et al. Antiobesity potential of Piperonal: promising modulation of body composition, lipid profiles and obesogenic marker expression in HFD-induced obese rats. Nutr Metab (Lond). 2017;14:72.

25. Floch J, Lees M, Sloane Stanley GHS. Simple method for the isolation and purification of total lipids from animal tissues. J Biol Chem. 1957;226:497-509.

26. Lira FS, Rosa JC, Pimentel GD, Tarini VAF, Arida RM, Faloppa F, et al. Inflammation and adipose tissue: effects of progressive load training in rats. Lipids Health Dis. 2010;9:109.

27. Badri KR, Gao L, Hyjek E, Schuger N, Schuger L. Exonic mutations of TSC2/TSC1 are common but not seen in all sporadic pulmonary lymphangioleiomyomatosis. Am J Respir Crit Care Med. 2013;187(6):663-5.

28. Xiao B, Sanders MJ, Carmena D, Bright NJ, Haire LF, Underwood E, et al. Structural basis of AMPK regulation by small molecule activators. Nat Commun. 2013;4:3017.

29. Duhovny DS, Inbar Y, Nussinov R, Wolfson HJ. PatchDock and SymmDock: servers for rigid and symmetric docking. Nucleic Acids Res. 2005;33:W363-7.

30. Hruby A, Hu FB. The epidemiology of obesity: A big picture. pharmacoeconomics. 2015;33(7):67389.

31. Friedman SL, Neuschwander-Tetri BA, Rinella M, Sanyal AJ. Mechanisms of NAFLD development and therapeutic strategies. Nat Med. 2018;24(7):908-22.

32. Viollet B, Guigas B, Leclerc J, Hebrard S, Lantier L, Mounier R, et al. AMP-activated protein kinase in the regulation of hepatic energy metabolism: from physiology to therapeutic perspectives. Acta Physiol (Oxf). 2009;196(1):81-98.

33. Auboeuf D, Rieusset J, Fajas L, Vallier P, Frering V, Riou JP, et al. Tissue distribution and quantification of the expression of mRNAs of peroxisome proliferator-activated receptors and liver $\mathrm{X}$ receptor-alpha in humans: no alteration in adipose tissue of obese and NIDDM patients. Diabetes. 1997;46(8):1319-27.

34. Gesta S, Tseng YH, Kahn CR. Developmental origin of fat: tracking obesity to its source. Cell. 2007;131(2):242-56.

35. Tontonoz P, Hu E, Spiegelman BM. Stimulation of adipogenesis in fibroblasts by PPAR gamma 2, a lipid-activated transcription factor. Cell. 1994;79(7):1147-56.

36. Barak Y, Nelson MC, Ong ES, Jones YZ, Ruiz-Lozano P, Chien KR, et al. PPAR gamma is required for placental, cardiac, and adipose tissue development. Mol Cell. 1999;4(4):585-95.

37. Spiegelman BM. PPAR-gamma: adipogenic regulator and thiazolidinedione receptor. Diabetes. 1998;47(4):507-14.

38. Auwerx J. PPAR gamma, the ultimate thrifty gene. Diabetologia. 1999;42(9):1033-49.

39. Nolan JJ, Ludvik B, Beerdsen P, Joyce M, Olefsky J. Improvement in glucose tolerance and insulin resistance in obese subjects treated with troglitazone. N Engl J Med. 1994;331(18):1188-93. 
40. Cavaghan MK, Ehrmann DA, Byrne MM, Polonsky KS. Treatment with the oral antidiabetic agent troglitazone improves beta cell responses to glucose in subjects with impaired glucose tolerance. $J$ Clin Invest. 1997;100(3):530-7.

41. Wang QA, Zhang F, Jiang L, Ye R, An Y, Shao M, et al. Peroxisome proliferator-activated receptor gamma and its role in adipocyte homeostasis and thiazolidinedione-mediated insulin sensitization. Mol Cell Biol. 2018;38(10):e00677-17.

42. Kim HI, Ahn YH. Role of peroxisome proliferator-activated receptor-gamma in the glucose-sensing apparatus of liver and beta-cells. Diabetes. 2004;53(Suppl 1):60-5.

43. Kawano Y, Cohen DE. Mechanisms of hepatic triglyceride accumulation in non-alcoholic fatty liver disease. J Gastroenterol. 2013;48(4):434-41.

44. Yu YH, Ginsberg HN. Adipocyte signaling and lipid homeostasis: sequelae of insulin-resistant adipose tissue. Circ Res. 2005;96(10):1042-52.

45. Knebel B, Fahlbusch P, Poschmann G, Dille M, Wahlers N, Stühler K, et al. Adipokinome signatures in obese mouse models reflect adipose tissue health and are associated with serum lipid composition. Int J Mol Sci. 2019;20(10):2559.

46. Weschenfelder C, Quadros AS, Santos JL, Garofallo SB, Marcadenti A. Adipokines and adipose tissue-related metabolites, nuts and cardiovascular disease. Metabolites. 2020;10(1):32.

47. Hawley SA, Davison M, Woods A, Davies SP, Beri RK, Carling D, et al. Characterization of the AMPactivated protein kinase kinase from rat liver and identification of threonine 172 as the major site at which it phosphorylates AMP-activated protein kinase. J Biol Chem. 1996;271(44):27879-87.

48. Carling D, Thornton C, Woods A, Sanders MJ. AMP-activated protein kinase: new regulation, new roles? Biochem J. 2012;445(1):11-27.

49. Gowans GJ, Hawley SA, Ross FA, Hardie DG. AMP is a true physiological regulator of AMP-activated protein kinase by both allosteric activation and enhancing net phosphorylation. Cell Metab. 2013;18(4):556-66.

50. Baur JA, Pearson KJ, Price NL, Jamieson HA, Lerin C, Kalra A, et al. Resveratrol improves health and survival of mice on a high-calorie diet. Nature. 2006;444(7117):337-42.

51. Lee YS, Kim WS, Kim KH, Yoon MJ, Cho HJ, Shen Y, et al. Berberine, a natural plant product, activates AMP-activated protein kinase with beneficial metabolic effects in diabetic and insulin-resistant states. Diabetes. 2006;55(8):2256-64.

52. Hawley SA, Ross FA, Chevtzoff C, Green KA, Evans A, Fogarty S, et al. Use of cells expressing gamma subunit variants to identify diverse mechanisms of AMPK activation. Cell Metab. 2010;11(6):55465.

53. Li Y, Xu S, Mihaylova MM, Zheng B, Hou X, Jiang B, et al. AMPK phosphorylates and inhibits SREBP activity to attenuate hepatic steatosis and atherosclerosis in diet-induced insulin-resistant mice. Cell Metab. 2011;13(4):376-88.

54. Feng S, Reuss L, Wang Y. Potential of natural products in the inhibition of adipogenesis through regulation of ppar gamma expression and/or its transcriptional activity. Molecules. 
2016;21(10):1278.

55. Fratev F, Tsakovska I, Sharif MA, Mihaylova E, Pajeva I. Structural and dynamical insight into ppar gamma antagonism: in silico study of the ligand-receptor interactions of non-covalent antagonists. Int J Mol Sci. 2015;16(7):15405-24.

56. Sozio MS, Lu C, Zeng Y, Liangpunsakul S, Crabb DW. Activated AMPK inhibits PPAR-\{alpha\} and PPAR-\{gamma\} transcriptional activity in hepatoma cells. Am J Physiol Gastrointest Liver Physiol. 2011;301(4):G739-47.

\section{Figures}

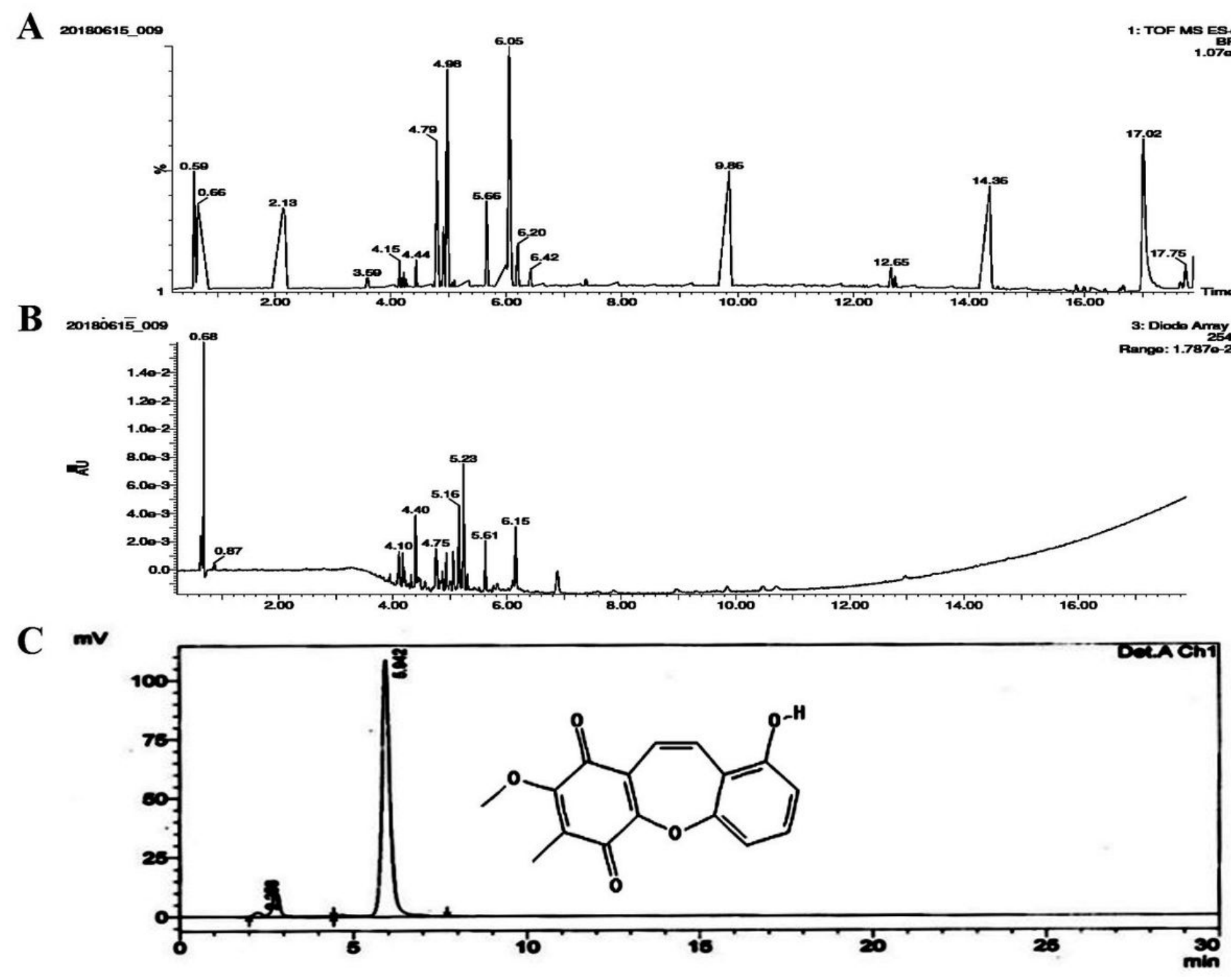

Figure 1

Molecular characterization of isolated compound/s from the chloroform fraction of Bauhinia purpurea ethanolic extract. (A-B) LC-MS analysis showing TOF MS ES+BPI and Diode Array (Retention Time) (C) 
HPLC peak representing structure and retention time (5.942) of BSTN1.
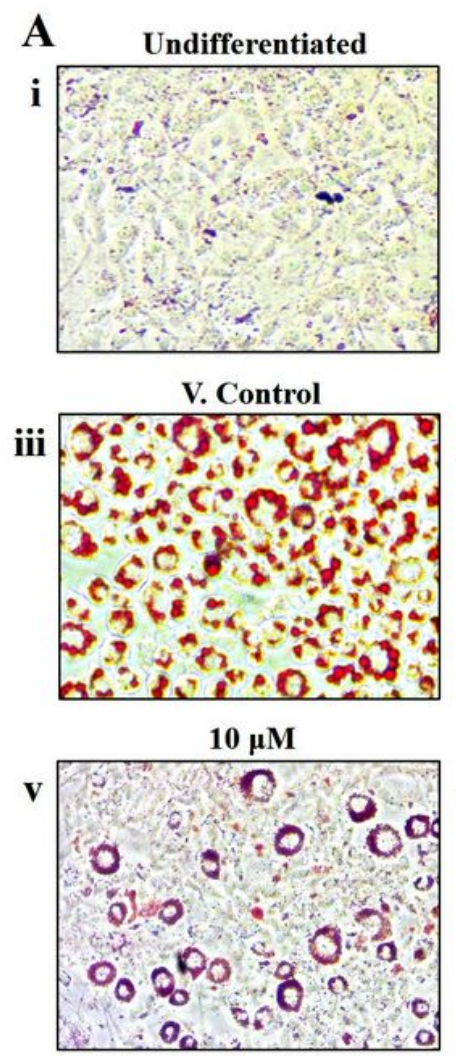
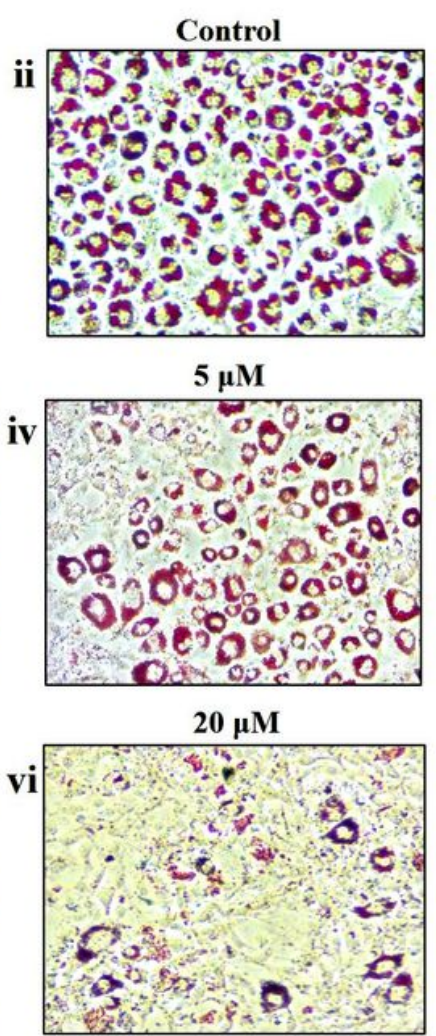

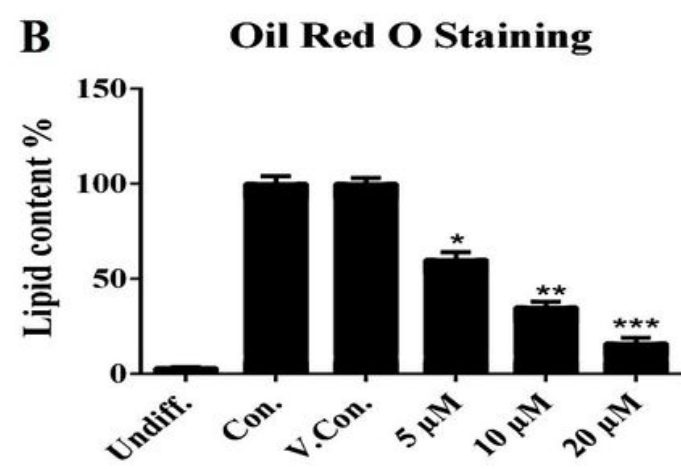

Bauhiniastatin-1 Conc.

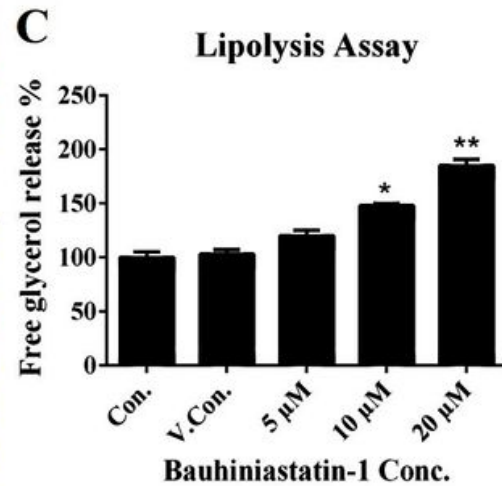

D

Cytotoxicity Assay

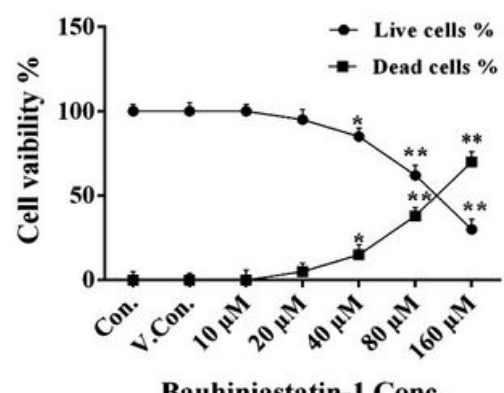

Figure 2

Effect of BSNT1 on 3T3-L1 cells. (A) Oil Red 0 stained 3T3-L1 cells illustrates decreased adipocytes counts, size and lipid droplets (Magnification 40X). (i) Undifferentiated untreated pre-adipocytes stained (ii) fully differentiated untreated adipocytes (control) stained (iii) differentiated DMSO $(0.01 \%)$ treated adipocytes (vehicle control). (iv), (v) and (vi) differentiated BSTN1 treated adipocytes (5, 10 and $20 \mu \mathrm{M})$ showing decreased adipogenesis in dose dependent manner. (B) Quantification of neutral lipid content (\%) by Oil Red 0 stain extraction in BSNT1-treated and other group cells. (C) Lipolysis assay indicating the amount of glycerol content released from 3T3-L1 adipocytes into the media. (D) Cytotoxicity assay results on the percentage of cell viability of untreated, DMSO and BSTN1 treated preadipocytes determined after $48 \mathrm{~h}$ using MTT assay. Data are presented as mean \pm SD of triplicate. $\left({ }^{*} p<0.05\right.$, $* \star$ $p<0.01$ and ${ }^{* \star *} p<0.001$ indicates significant difference between untreated and treated 3T3-L1 cells). 


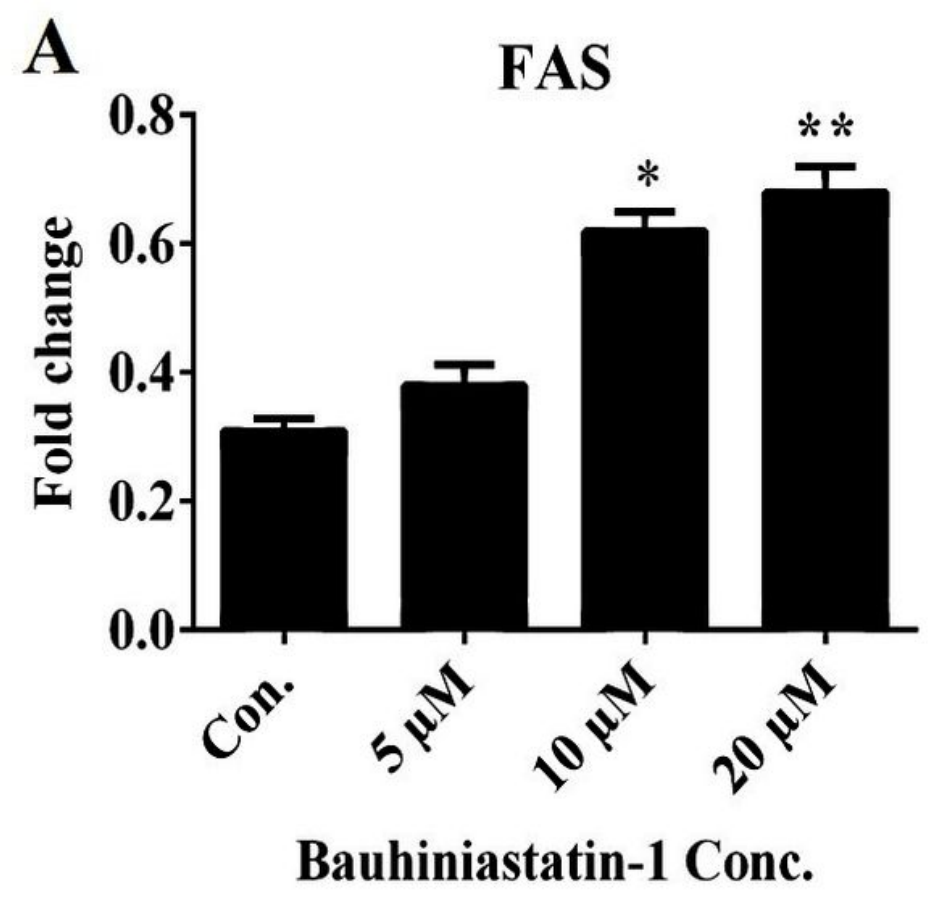

B SREBP1

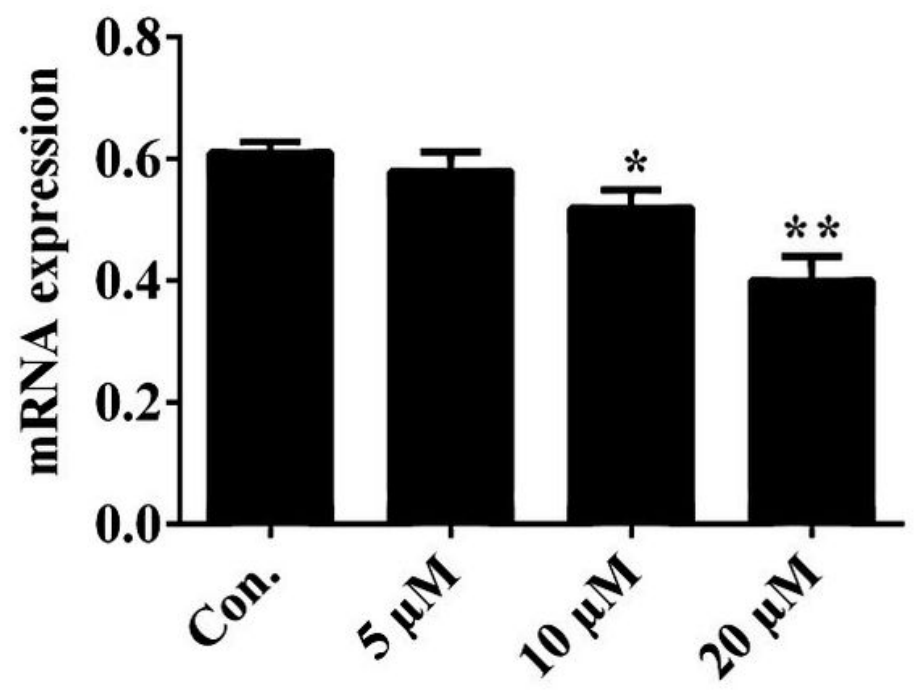

Bauhiniastatin-1 Conc.
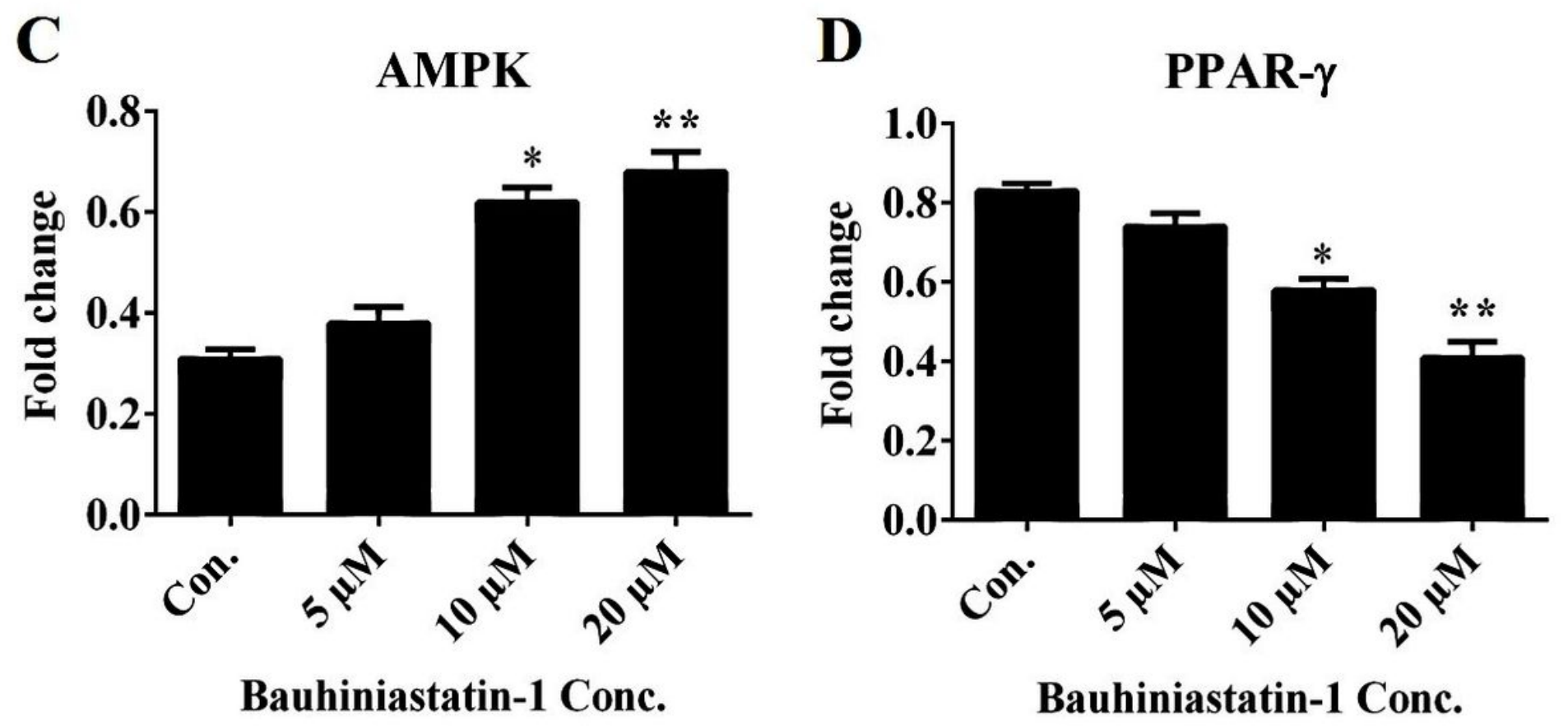

Figure 3

Effect of BSTN1 on the quantitation of fold change of key adipogenic and lipogenic markers in 3T3-L1 adipocytes. (A) FAS, (B) SREBP1, (C) AMPK and (D) PPAR- $\gamma$. Data are presented as mean \pm SD of triplicate. ( ${ }^{*} p<0.05$ and ${ }^{* *} p<0.01$ indicates significant difference between untreated and treated 3T3-L1 cells). 
A

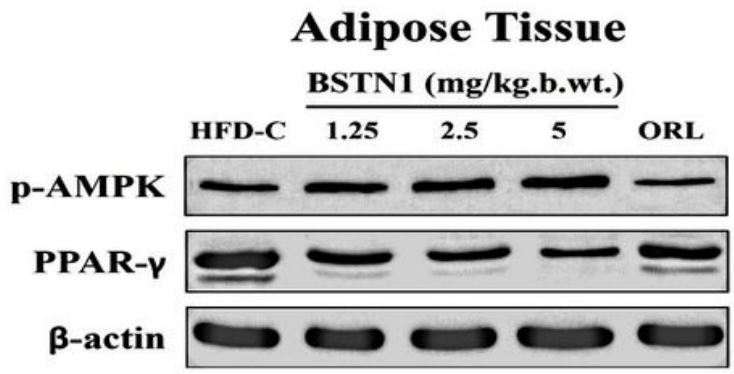

C

Adipose Tissue

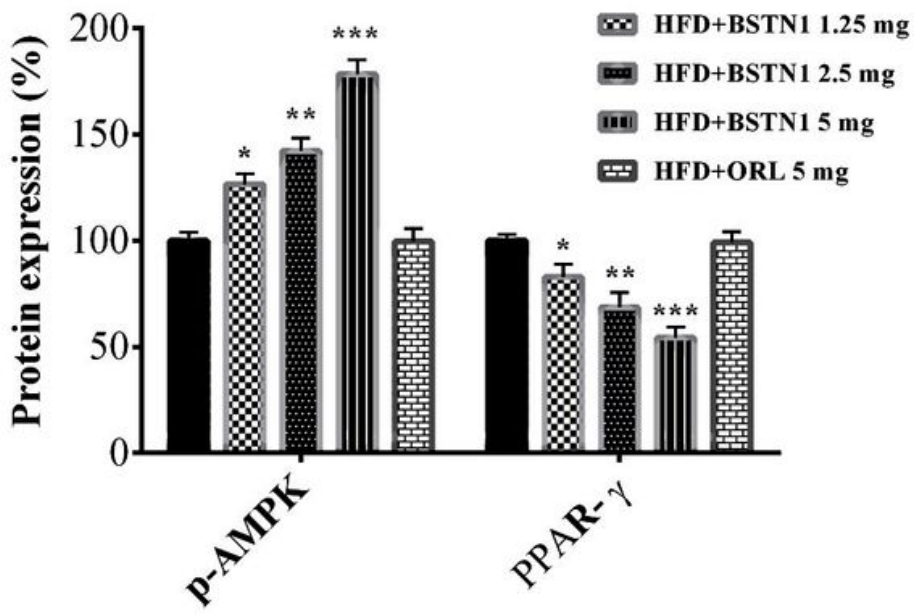

B Hepatic Tissue BSTN1 (mg/kg.b.wt.)

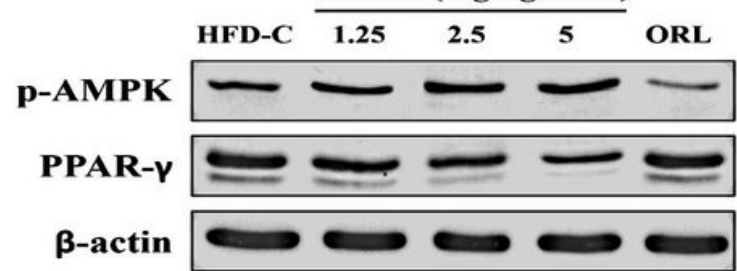

D

Hepatic Tissue

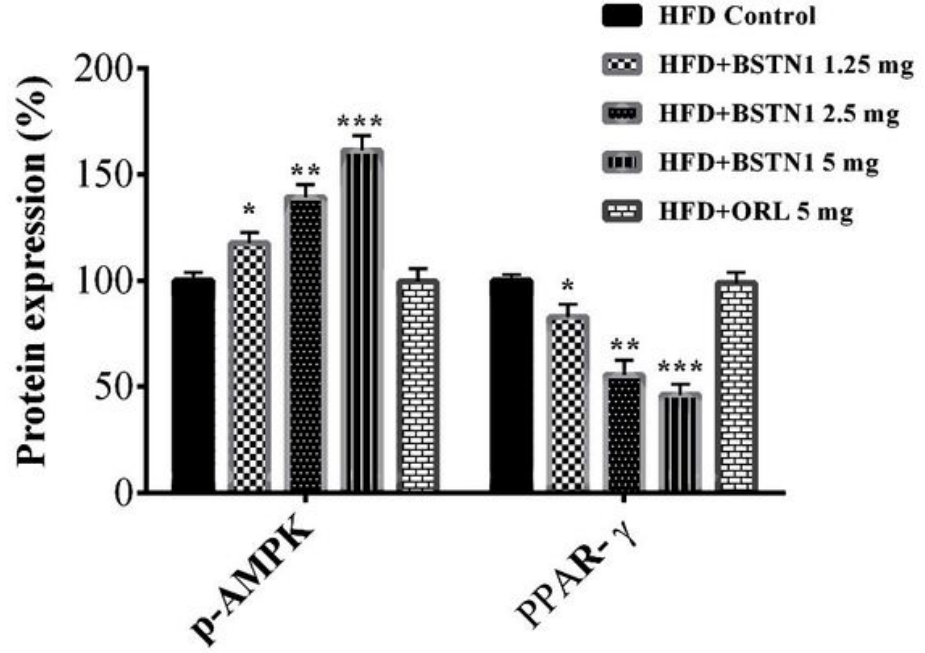

Figure 4

Western blot analysis reveals the effect of BSTN1 on protein expression of p-AMPK and PPAR-y in (A) adipose and (B) hepatic tissues. Quantitation of (C) white adipose - p-AMPK/PPAR- $y$ and (D) hepatic $\mathrm{p}$-AMPK/PPAR- $\gamma$ are represented in histograms. Histograms represent mean \pm standard deviation. $\beta$-actin is used as a housekeeping gene. ( ${ }^{*} p<0.05$ and ${ }^{* *} p<0.01$ indicates significant difference between HFD-C (HFD-control) (placebo) and treated groups). 
A

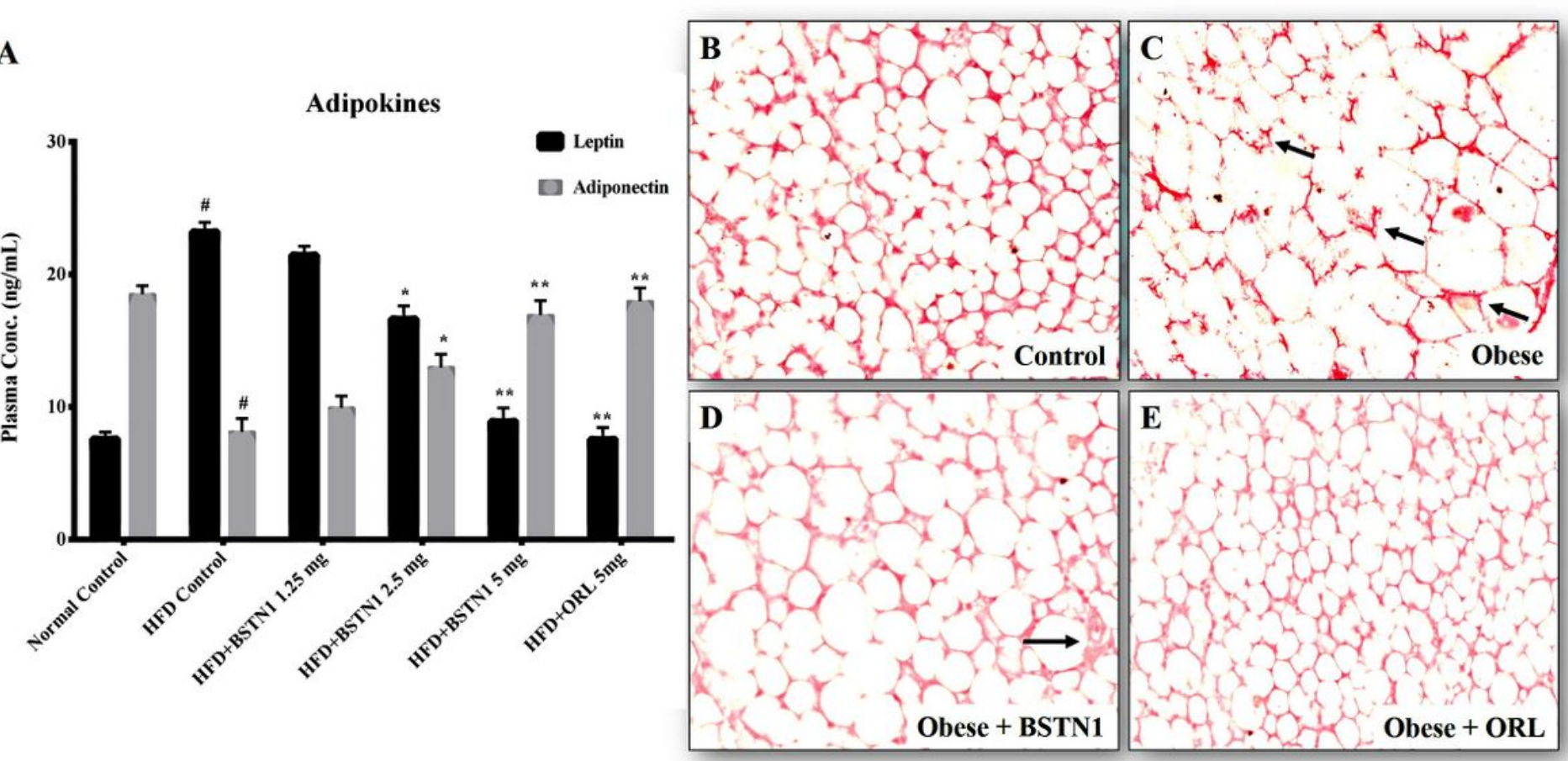

Figure 5

Effect of BSTN1 on adipokines and histology of white adipose tissue. (A) Plasma adipokines levels represented as mean $\pm S D$, $(n=6)$. (B-E) Effect of BSTN1 on adipocytes morphology and histopathology of white adipose tissue (H\&E staining, 10x magnifications) in normal control and HFD-fed rats. (B) Normal control white adipose tissue illustrating normal adipocyte morphology. (C) histology of obese rat's adipose tissue illustrates distracted and enlarged adipocytes. (D-E) BSTN1 (5 mg) and Orlistat (5 mg) treated obese rat's show smaller adipocytes than the adipocytes of obese untreated group. \# $p<0.001$ indicate significant difference between HFD control and normal control groups. * $p<0.05$ and ** $p<0.01$ indicates significant difference between HFD control (placebo) and treated groups. 
$\mathbf{A}$

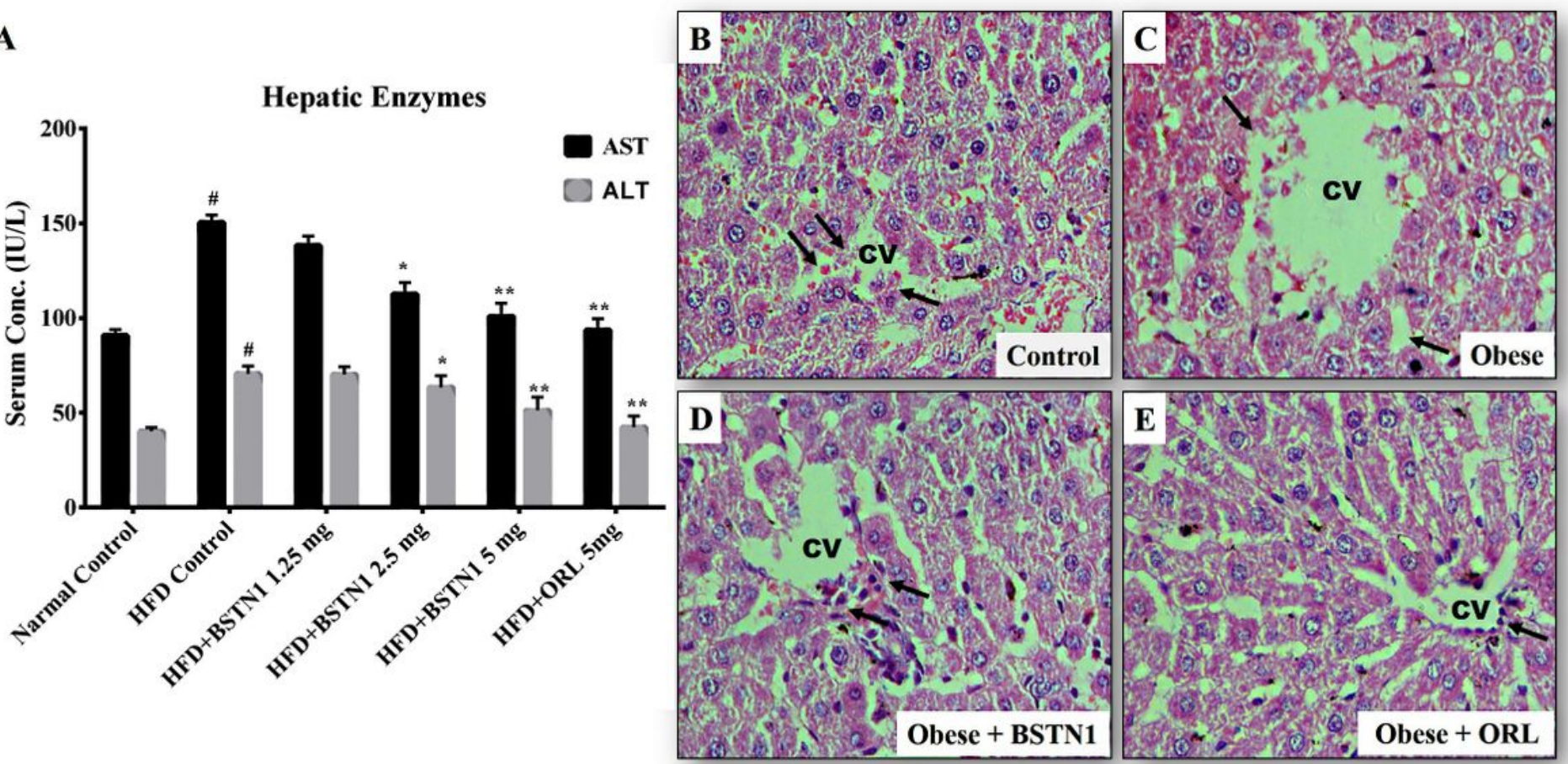

Figure 6

Effect of BSTN1 on liver enzymes (AST \& ALT) levels and liver tissue. (A) Serum AST and ALT levels represented as mean $\pm S D$, $(n=6)$. Effect of BSTN1 on liver morphology and histopathology (H\&E staining, 40X magnifications) in normal control and HFD-fed rats. (B) Normal control groups hepatic tissue illustrates central vein (cv) with endothelial lining (arrows), hepatocytes, sinusoidal spaces with Kupffer cells. (C) Obese untreated group animals show non-alcoholic fatty liver illustrating accumulated small lipid droplets, deranged hepatocyte morphology in different areas with enlarged central veins (with some tissue destruction) and increased leucocytic infiltrations into the vein and in between vacuolations (arrows, as damage hallmarks). (D) BSTN1 (40 mg) treated obese rat's liver show tissue architecture close to normal livers with less accumulation of fat and tissue architecture including cv. (E) Orlistat treated obese rat's liver histology shows improvement compared to HFD-control. \# p<0.001 indicate significant difference between HFD control and normal control groups. * $p<0.05$ and ** $p<0.01$ indicates significant difference between HFD control (placebo) and treated groups. 

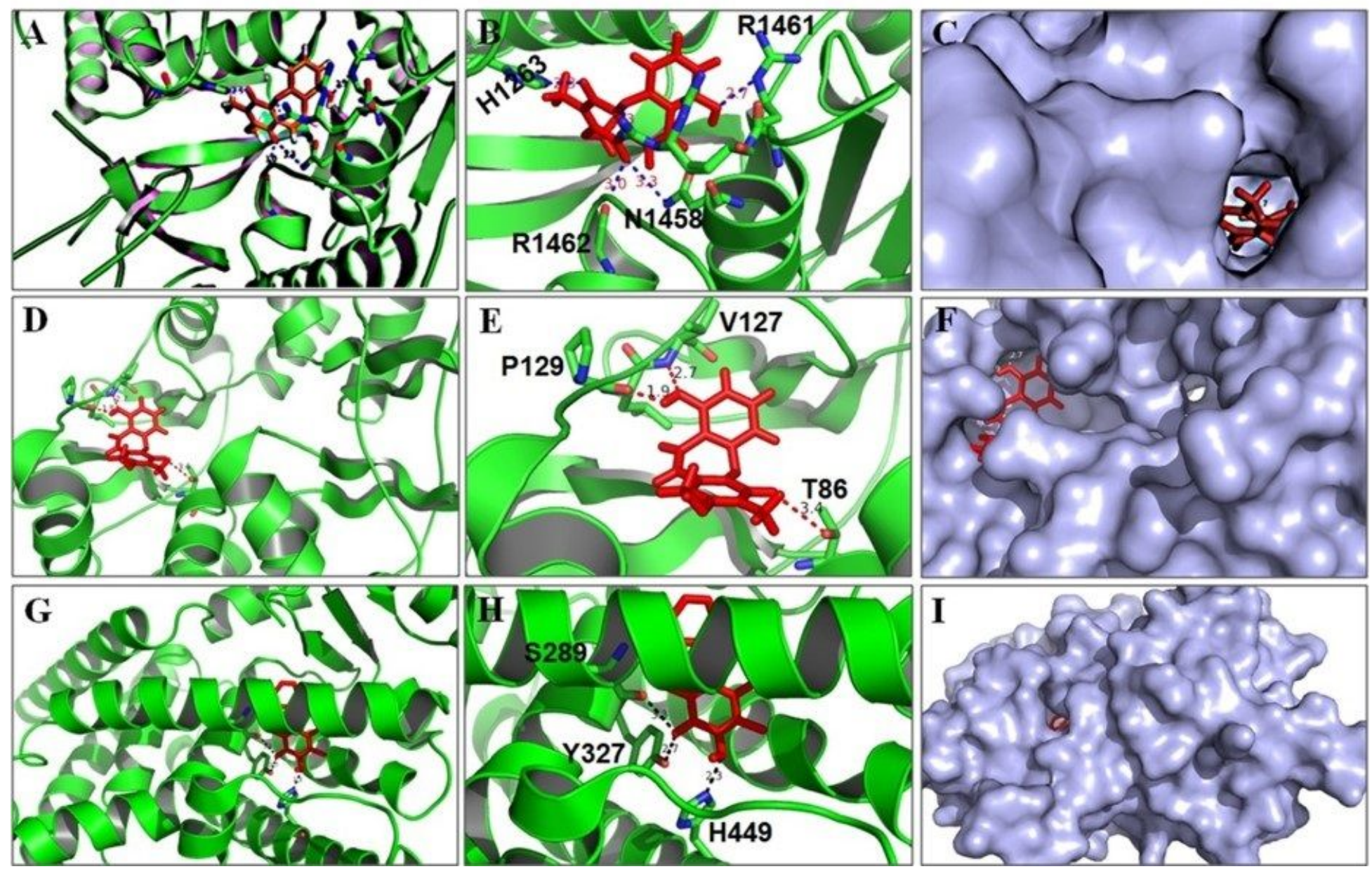

Figure 7

BSNT1 docking to FAS, AMPK and PPAR-y. (A-C) Computational docking of BSTN1 (red) with the FAS (6NNA). (D-F) Computational docking of BSTN1 (red) with the amino acids of targeting AMPK (6C9F). (GI) Computational docking reveals the BSTN1 (red) strongly interacts with hydroxyl and amino groups of the tyrosine, serine and histidine residues of PPAR-y (3WMH).

\section{Supplementary Files}

This is a list of supplementary files associated with this preprint. Click to download.

- BSTN1Suppl.xlsx

- GraphicalAbstract.jpg 